\title{
Topos indyjskiego bohatera epickiego, czyli wyobrażenie władcy doskonałego w Mahabharacie
}

\author{
Topos of the Indian Epic Hero or the Image of Perfect Sovereign as Shown in the Mahābhārata
}

\begin{abstract}
The article is an analysis of some chosen fragments of the Indian epic Mahābhärata. They are chosen in order to check whether, on the basis of them, it is possible to establish the topos of an ideal Indian epic hero. The excerpts come mainly from book three of the epic Vanaparvan and from book one, Addiparvan. The material gathered enables to give the positive answer to the question. The male characters are described there in detail. The given features are so typical that they re-apper in most of the cases. First of all, in the text one can find the descriptions of five heroes of the main narrative, the Paṇava brothers - Yuddișthira, Bhima, Arjuna, Nakula and Sahadeva. Additionally, several fragments in which the features of sub-stories' male characters, such as e.g. Aśvapati or Nala, are discussed. The final result of the analyse brings several observations. The typical epic sovereign should have the virtues of both the spritual and physical nature. Most of the heroes of the chosen fragments are described as the ones who should be full of all kind of virtues, just and generous. They cannot be liars. They should fulfill the rights of dharma as far as the obligations of kings are concerned. They should look after their subjects, their wives and families. As far as their bodies are concerned they hàve to be handsome, bright and good to look at. Their faces are compared to the moon or the sun. Their eyes are described as wide and often compared to the lotus petals. Their noses are aquiline. They should be strong and delicate at the same time. Their images are sometimes built with the usage of comparisons to different members of the Vedic pantheon. The most popular comparisons are to Indra and Agni. However, also Kama, Aditya and some others do appear not excluding the demi-gods such as Gandharvas or Yakshas.
\end{abstract}

Keywords: Indian epic, Mahābhārata, epic hero, topos

Jeżeli epopeja chce mile zabawić

I nigdy czytelnika w tęsknotę nie wprawić,

Niech dzieje bohatera wielkiego opiewa,

Takiego, co się chwały miłością zagrzewa,

Który przez cnoty swoje, przez broni swej dzielność 
Sprawiedliwie zarobił sobie nieśmiertelność;

Niechaj w nim coś wielkiego same wady mają ${ }^{1}$.

Artykuł ten jest próbą odpowiedzi na pytanie o to, czy jest możliwe określenie charakterystycznych cech głównych bohaterów indyjskich tekstów epickich na przykładach wybranych z jednego z dwóch najważniejszych eposów Indii, czyli z Mahabharaty ${ }^{2}$. Analizie zostaną poddane wyobrażenia bohaterów - władców jako jednej z kategorii postaci występujących w eposie relatywnie najczęściej. Czy zestaw przypisywanych im cech można uznać za topos indyjskiego bohatera epickiego? Materiał źródłowy wybrany do analizy jest z konieczności ograniczony $^{3}$. Wybrane fragmenty posłużą analizie postaci władców przedstawianych w opisach zawartych zarówno w fabule głównej, jak i w wątkach pobocznych. Gama postaci męskich przedstawianych w Mahabharacie obejmuje znacznie więcej kategorii. Poza tą analizowaną w niniejszym tekście jedną z najpełniej opisanych jest kategoria ascetów ${ }^{4}$. Jest oczywiste, że w dziele tak ogromnym i wielowątkowym jak Mahabharata ${ }^{5}$ bohaterowie $\mathrm{z}$ innych jeszcze kategorii posiadają cechy, które można by określić jako typowe.

${ }^{1}$ F.K. Dmochowski, Sztuka rymotwórcza, Wrocław 1956, s. 94.

${ }^{2}$ Ze względu na język artykułu imiona i terminy sanskryckie podaję w ich spolszczonej formie (z wyjątkiem przypadków kiedy odwołuję się bezpośrednio do języka oryginału).

${ }^{3}$ Materiał ten mógłby być znacznie obszerniejszy. Przede wszystkim mógłby obejmować tekst drugiego z indyjskich eposów, Ramajany. Jego głównym bohaterem jest król Rama, uznawany przez wielu badaczy za wzór bohatera epickiego. O Ramie pisano już jednak bardzo obszernie. Szczegółowe analizy znaleźć można np. w pracach jednego z najwybitniejszych znawców przedmiotu Johna Brockingtona (zob. J. Brockington, The Sanskrit Epics, Leiden 1998; idem, Righteous Rama. The Evolution of an Epic, Delhi 1984, i in.). W drugiej z przywołanych tu książek Brockington duży fragment jednego z rozdziałów poświęcił właśnie analizie cech bohatera (s. 124-152). Kolejną kategorię tekstów epickich, które można by wykorzystać do wszelakiej natury rozważań i porównań, mogłyby stanowić purany, teksty pełne opowieści o dawnych władcach. Purany to jednak dzieła tak obszerne, że wymagałyby one niewątpliwie odrębnej, pogłębionej analizy. Ich zawartość szacuje się na około 400 tys. strof (zob. L. Rocher, The Purānas, Wiesbaden 1985; K. Mylius, Historia literatury staroindyjskiej, Warszawa 2004, i in.). Już przy pobieżnej analizie tych dzieł można jednak stwierdzić, że po wielokroć topos bohatera - doskonałego władcy jest w nich podobny bądź wręcz tożsamy z tym, który można odnaleźć w wielu fragmentach Mahabharaty. Najstarsze purany, jako dzieła datowane na okres najprawdopodobniej późniejszy niż ramy powstawania eposów, byłyby wtórne względem wzorów, które występują w Mahabharacie. Krótki przegląd treści najstarszych puran można znaleźć w pracach dotyczących historii literatury staroindyjskiej. Pośród nich jednym z pierwszych europejskich opracowań była wydana w 1907 r. A History of Indian Literature autorstwa M. Winternitza (zob. M. Winternitz, A History of Indian Literature, vol. I, [rep.] Delhi 1990, s. 51-552).

${ }^{4} \mathrm{Na}$ ten temat pisze np. autorka tego artykułu (zob. I. Milewska, Ze studiów nad Mahabharata, Kraków 2013, s. 175-179).

${ }^{5}$ Tradycyjnie liczbę strof Mahabharaty określa się na około 100 tys. Tak właśnie jej obszerność opisywana jest w historiach literatury staroindyjskiej (zob. A.A. Macdonell, A History of Sanskrit Literature, [rep.] Delhi 1990, s. 237; M. Winternitz, op. cit., s. 301). Pośród współczesnych badaczy do takiej tezy przychyla się np. A.N. Jani (A.N. Jani, The Mahäbhārata as an Organic Growth of the Oral Literary Tradition in Ancient India, [w:] The Mahābhārata Revisited. Papers presented at the International Seminar on the Mahäbhārata organized by the Sahitya Akademi New Delhi on February 17-20, 1987, ed. R.N. Dandekar, New Delhi 1990, s. 71-85). Różnicuje on jednak ilość strof ze względu na wydanie krytyczne, do którego się odwołuje. Według najnowszych badań obszerność Mahabharaty określa się jednak na około 75 tys. strof (zob. J. Brockington, The Sanskrit..., s. 2). 
Bohater - władca jest w Mahabharacie najczęściej opisywany jako władca idealny. Jego podstawowe cechy są zarówno duchowej, jak i fizycznej natury. Szczegółowe opisy dotyczą tak bohaterów głównej fabuły, jak najważniejszych postaci poszczególnych, wtrącanych w tok narracji i możliwych do wyodrębnienia pomniejszych opowieści. Często, choć nie jest to regułą, można odnaleźć w tych opisach porównania do stereotypowych cech przypisywanych poszczególnym niebianom ${ }^{6}$ wedyjskiego jeszcze panteonu. Niebianinem najczęściej przywoływanym w takich kontekstach jest władca tychże - Indra ${ }^{7}$. Królowie mogą być porównywani także do innych niebian, na przykład do Agniego, wiązanego $\mathrm{z}$ fenomenem ognia i ofiary ${ }^{8}$. Relatywnie często w porównaniach przywoływany jest też niebianin Kama (jego inne, występujące w niektórych z porównań, imię to Kandarpa). Ten ostatni jest silnie związany z fenomenem miłości ${ }^{9}$. Bohater może być także określany mianem Brihaspatiego, niebianina odpowiadającego za ofiary tak niebieskie, jak ziemskie, czy Aditji, jednego z synów niebianki Aditi ${ }^{10}$. W takich kontekstach określa się bohaterów między innymi jako „nieśmiertelnych” czy „podobnych nieśmiertelnym” (amaropama).

B.M. Sullivan, inny współczesny badacz, precyzuje tę liczbę na 73 tys. strof w wydaniu krytycznym i 84 tys. strof w XVII-wiecznym wydaniu, które ukazało się wraz z obszernym komentarzem (zob. B.M. Sullivan, Kṛṣna Dvaipāyana Vyāsa and the Mahābhārata. A New Interpretation, Leiden 1990, s. 2).

${ }^{6}$ Przedstawicieli wedyjskiego panteonu określam, wbrew powszechnie używanemu przez zachodnich indologów terminowi „bogowie”, mianem ,niebianie”, idąc w takiej interpretacji za M.K. Byrskim i jego argumentacją wyłożoną w książce Spotkanie z hinduizmem (M.K. Byrski, Spotkanie z hinduizmem, Warszawa 2016, s. 18-19). Byrski wskazuje na to, iż niebianie są czymś mniej niż bogowie.

${ }^{7} \mathrm{O}$ bogu Indrze pisano w wielu, opartych na źródłach oryginalnych, opracowaniach dotyczących mitologii indyjskiej (zob. E.W. Hopkins, Epic Mythology, Strassburg 1915; W.J. Wilkins, Hindu Mythology, New Delhi 2013). Wyobrażenia boga Indry można znaleźć w różnych źródłach. Wilkins, poświęcając mu jeden z rozdziałów książki, pisze, że wedyjski władca niebios Indra dzierży w rękach piorun, którego oślepiającym blaskiem oświetla niebo. Jest bogiem deszczu, który zsyła na ziemię, by w najtrudniejszych okresach, gdy ziemię pustoszą susze, pomagać jej mieszkańcom. Zwykle przedstawia się go jako jadącego na słoniu, posiadającego dwie lub cztery ręce. Jest doskonałym wojownikiem, którego przeciwnicy nie są w stanie pokonać. To Indra epoki wedyjskiej. W późniejszych dziełach wyobrażenie Indry się zmienia. Epos jednak najczęściej odwołuje się do wyobrażeń wedyjskich. Marta Jakimowicz-Shah w książce Metamorfozy bogów indyjskich omawia funkcje boga w mitologii i pisze, iż jest on często przedstawiany jako forma słońca i w związku z tym - jako złocisty lub pomarańczowy (zob. M. Jakimowicz-Shah Metamorfozy bogów indyjskich, Warszawa 1983, s. 38).

${ }^{8}$ Agni jest władcą, obrońcą i królem ludzi. Jest panem każdego domu, pośrednikiem między światem bogów i ludzi. Często w mitologii wedyjskiej jest przedstawiany jako posiadający trzy nogi i siedem ramion. Płonie czerwienią, jest czarnowłosy. Ma ciemne brwi i oczy. Z jego ust wydobywają się płomienie ognia. Z kolei całe jego ciało jaśnieje światłem (W.J. Wilkins, op. cit., s. 21-22). M. Jakimowicz-Shah pisze, że Agni-Ogień przejawia się w trzech postaciach - jako słońce na niebie, błyskawica w powietrzu i ogień na ziemi. Opisuje go jako czerwonoskórego posiadacza palącej się korony (M. Jakimowicz-Shah, op. cit., s. 39).

9 Kama jest niebianinem, którego pełniejsze wyobrażenie pojawia się w literaturze późniejszej niż okres wedyjski. Najczęściej jest opisywany jako syn bogini Lakszmi i boga Wisznu. Zwykle jest przedstawiany jako piękny młodzieniec trzymający w rękach łuk, którego cięciwę stanowią pszczoły, a strzały to kwiaty (W.J. Wilkins, op. cit., s. 249).

${ }^{10} \mathrm{Ci}$ dwaj ostatni niebianie czasami występują jako odpowiedniki Indry. Porównania do nich mają za cel przede wszystkim pokazanie bohaterów jako podobnych do niego. 
Używa się porównań takich jak „mąż podobny bogu” czy „król podobny bogu Indrze" (nareśvara, rajendra). Odpowiednikiem niektórych z bohaterów bywa także pierwszy z ludzi, mityczny praojciec ludzkości Manu ${ }^{11}$. Porównuje się ich też do istot o charakterze półboskim, takich jak choćby niebiańscy muzycy i śpiewacy zwani Gandharwami ${ }^{12}$, czy do Jakszów, których jedną z ról było opiekowanie się ludźmi ${ }^{13}$. Jest tak, jak pisał kiedyś jeden z pierwszych autorów zajmujących się literaturą indyjską w Polsce, Julian Adolf Święcicki:

Cudowność i ów hiperbolizm wschodni, t.j. owa przesada potworna, w której Indyanie są nade wszystko rozmiłowani, panuje tak dobrze w Mahabharacie, jak w Ramayjanie. Opowieść nie ma ograniczeń żadnych ani w czasie, ani w przestrzeni i w liczbach; wszystko się tu liczy na miliony lat. Nie istnieją również granice epiczne pomiędzy boskością a człowieczeństwem; a bogowie i pół bogi zjawiają się na świecie, jak ludzie i zwierzęta ${ }^{14}$.

Nie sposób wymienić wszystkich czy nawet większości kontekstów, w których w Mahabharacie opisywani są bohaterowie będący władcami królewskimi. Konieczne jest zatem kolejne zawężenie materiału źródłowego. Księgą, w której można znaleźć bardzo dużą liczbę przykładów odnoszących się do tematu bohatera epickiego, jest Aranjakaparwan, „Księga pouczeń leśnych” (āranyakaparvan), inaczej nazywana Wanaparwan, czyli „Księgą lasu” (vanaparvan). To ona właśnie, uzupełniona o fragmenty pochodzące z Adiparwan, „Księgi wstępnej” (ādiparvan), jest podstawą niniejszej analizy ${ }^{15}$. Księga trzecia jest szczególnie ciekawa ze względu na dużą liczbę historii czy epizodów wtrącanych w fabułę opowieści głównej. Dzięki temu odbiorca ma tu do czynienia z całą gamą bohaterów, co stanowi niewątpliwie dobrą podstawę do analizy porównawczej ich

11 Informacji na temat Manu dostarcza np. jeden z niezwykle ważnych dla tradycji indyjskiej tekstów, Manusmriti (zob. Manu Swajambhuwa, Manusmryti czyli Traktat o Zacności, przełożyl z oryginatu sanskryckiego, wstępem, przedmowa, przypisami i słowniczkiem opatrzył Maria Krzysztof Byrski, Warszawa 1992).

12 Opis pochodzenia i ról spełnianych przez Gandharwów jest różny w zależności od okresu, w którym powstawały teksty zawierające ich wyobrażenia. Według jednego z najpowszechniej do tej pory używanych przez indologów słownika, opracowanego pod kierunkiem M. Moniera-Williamsa, w okresie epickim Gandharwowie to ,,The celestial musicians or heavenly singers who form the orchestra at the banquets of the gods, and they belong together with the Apsarasas to Indra's heaven" (zob. M. Monier-Williams, A Sanskrit-English Dictionary Etymologically and Philologically Arranged with Special Reference to Greek, Latin, Gothic, German, Anlo-Saxon and Other Cognate Indo-European Languages, [rep.] Delhi 1993, s. 346). Podobnie pisze o nich w swoim słowniku John Dowson: „Those of Indra's heaven are generally intended by the term, and they are singers and musicians who attend the banquets of the gods" (zob. J. Dowson, A Classical Dictionary of Hindu Mythology and Religion, Geography, History and Literature, [rep.] Delhi 1987, s. 105-106). Krótki opis dotyczący tych półboskich postaci można znaleźć także w wydanym w 1994 roku Słowniku mitologii hinduskiej (zob. Słownik mitologii hinduskiej, Warszawa 1994, s. 68).

13 Jakszowie według słownika M. Moniera-Williamsa to „Class of semi-divine beings” (M. Monier-Williams, op. cit., s. 838). Identycznie opisuje ich Dowson (J. Dowson, op. cit., s. 373). Krótki opis Jakszów jest także zawarty we wspominanym wyżej słowniku (Słownik mitologii hinduskiej, s. 84-85). W wielu wyobrażeniach są to odnoszące się do ludzi życzliwie bóstwa opiekuńcze.

14 J.A. Święcicki, Literatura indyjska, Warszawa 1902, s. 229.

15 Odpowiednio są to księgi III i I. W podawanych przeze mnie w artykule przykładach wszystkie lokalizacje w tekście oryginalnym będą odnosić się do wydania krytycznego Mahabharaty (The Mahābhārata, eds. V.S. Sukthankar et al., vol. 1-19, Poona 1933-1966). 
wyobrażeń, ich cech charakterystycznych. Zawartość tej księgi umożliwia też próbę odpowiedzi na pytanie, czy można mówić o toposie bohatera epickiego na podstawie wybranych fragmentów Mahabharaty ${ }^{16}$.

Wielu z władców w Mahabharacie określa się ogólnymi sanskryckimi terminami rājan „król, władca"17 bądź mahārājan „wielki król, władca władców”. Stosowane są one wymiennie z określeniami mahīpati bądź prthivīpati, pārthiva czy prthivīpāla, które można tłumaczyć jako „pan ziemi”, „,władca ziemi” czy „strażnik ziemi”. Znaleźć można też w tekście i inne określenia natury ogólnej. Są to najczęściej złożenia takie jak narādhipa, nrpa, manujādhipa czy janādhipa. Te z kolei znaczą tyle co „obrońca ludzi, król ludzi”. W tych opisach, w których mamy do czynienia jedynie z określeniami natury ogólnej, każdy z królów jest zatem pokazywany jako ten, który jako władca ziemi jest zobowiązany do dbania o swoich poddanych.

Niewątpliwie charakterystyczne cechy natury ogólnej odnoszące się do doskonałych bohaterów - epickich królów można odnaleźć w wyobrażeniach związanych z męskimi postaciami fabuły głównej Mahabharaty. Są nimi przede wszystkim bracia Pandawowie, pozytywni bohaterowie eposu. Opisywane są zarówno ich zalety duchowe, jak i relatywnie ściśle określane cechy natury fizycznej. W jednym z fragmentów księgi trzeciej Mahabharaty (Mbh.III.254.7-254.20) Draupadi, ich wspólna żona, pokrótce charakteryzuje każdego z nich. Judhiszthira, najstarszy z braci ma jasną karnację, jego ciało błyszczy jak złoto, ma orli nos. Jest szczupły i ma ogromne oczy. Jest przywódcą rodu Kuru i zarazem synem boga Dharmy, dlatego zawsze, w jej przekonaniu, postępuje zgodnie z regułami odwiecznego prawa, zarówno natury religijnej, jak i ziemskiej (dharma $)^{18}$. Kolejnego z braci, Bhimę, określa jako posiadającego niezwykle mocne ramiona i podobnego do drzewa Śala ${ }^{19}$. Jego działania porównuje do czynów przekraczających ludzkie możliwości (etasya karmānyatimānușāni ). Ardżuna z kolei jest według niej delikatny i szczodry. Panuje nad swoimi zmysłami i szanuje starszych ${ }^{20}$, a także bez względu na okoliczności - ani z miłości, ani z pożądania, ani z lęku - nie porzuca reguł prawa. Nigdy nie postępuje okrutnie, mimo że często zwycięża w walkach z wrogami. Blaskiem podobny jest do boga Agniego ${ }^{21}$. Nakulę, kolejnego $\mathrm{z}$ braci, określa jako tego, który zna wszystkie reguły prawa boskiego i ziemskiego, nieustraszonego i posiadającego najpiękniejsze ciało na ziemi ${ }^{22}$. Ostatniego, Sahadewę, opisuje

16 Wielość opowieści wtrącanych w tok narracji głównej obliczana jest na 4/5 całego eposu. To jednak księga trzecia w opinii wielu badaczy zawiera ich najwięcej (zob. np. A.A. Macdonell, op. cit., s. 247).

${ }_{17}$ Termin rājan bywa stosowany do szerokiej gamy znaczeń, od przywódcy plemiennego aż do monarchy absolutnego (zob. J. Brockington, Righteous Rāma..., s. 124).

18 ya eșa jāmbūnadaśuddhagauraḥ praćaṇdaghoṇastanurāyatākṣah / etam kuruśreșthatamam vadanti yudișthiram dharmasutam patim me //

19 mahābhujam śālamiva pravṛddham /

${ }_{20}$ mrduvadānyo dhritimānyaśasvī jitendriyo vṛddhasevī nrvīrah /

21 yo vai na kāmānna bhayānna lobhāttyajeddharmam na nr̦śammisam ca kuryāt / so eșa vaiśvānaratulyatejāsaḥ...

${ }^{22}$ yaḥ sarvadharmārthaviniścayajńo bhayārtānām bhayahartā manīṣ̄ / yasyottamam rūpamāhuḥ prthivyām... 
jako zręcznego w walce, silnego i mądrego ${ }^{23}$. Jego waleczność porównuje do odwagi Indry. Dodatkowo mówi o nim, że blaskiem jest podobny do promieni księżyca (ya eșa candrārkasamānatejā). Jest bohaterem o umyśle, który nie ma sobie równych na ziemi (buddhyā samo yasya naro na vidyate), świetnym mówcą (vaktā tathā satsu viniścayajńa), nieustraszonym i nieustępliwym w walce wojownikiem (amarșana). Jest tak mądry, jak roztropny (dhìmānprājńa). Sahadewa podobnie jak pozostali bracia nigdy nie przekracza, zdaniem Draupadi, reguł odwiecznego prawa obowiązującego każdego króla (sadā manasvī kșatradharme $)^{24}$. Warto wspomnieć, że według niektórych badaczy Mahabharaty - tych, którzy w swoich interpretacjach eposu podążają ścieżką wytyczoną przez S. Wikandera i G. Dumézila - dopiero wszyscy Pandawowie razem składają się na jednego doskonatego bohatera ${ }^{25}$.

Królowie opisywani są także wielokrotnie w opowieściach wtrącanych w główny wątek eposu. W sferze duchowej charakteryzują się oni cechami podobnymi do wyżej opisanych, wymaganymi przez prawo, a zatem pożądanymi. Na podstawie zgromadzonych kontekstów można stwierdzić, że zestaw tych cech, jako powtarzający się w nieodmiennej często postaci, jest ściśle skonwencjonalizowany. Terminy ogólne, jakimi są określani władcy, to: „pełen wszelkich cnót”, „ozdobiony wszystkimi cnotami”, „ten, który jest niezwykle prawy” czy „mąż strzegący reguł prawa" (sarvagunairyukta, sarvagunopeta, paramadhārmika, vìro dharmeno paripālaya). Są oni znawcami odwiecznego prawa, zarówno jeśli chodzi o religię, jak i reguły obowiązujące na ziemi (dharmavid, dharmajńa, dharmātma, dharmabhṛt). Są określani jako pobożni (punyaśloka). Znają nauki zawarte w świętych tekstach, przede wszystkim w Wedach i Wedangach (vedavid, vedavedañgapāraga). Są gorliwi i dokładni w składaniu ofiar, które według prawa powinni inicjować i odprawiać (brahmanya). Charakteryzuje ich też odpowiedni stosunek do braminów. Szanują ich i obdarzają dobrami natury materialnej w podzięce za pomoc w składaniu ofiar. Są prawdomówni (satyavādin, satyavikrama, satyasambandha, satyavāk) i szczodrzy (dānapati, udāra). Panują nad swoimi zmysłami (jitendriya, vijitendriya, samyatendriya). Są sprawiedliwi i opiekuńczy (śaranya) względem swoich poddanych. Są ich obrońcami (rakșitṛ). Ich szczególną cechą jest dbanie o bezpieczeństwo własnych żon. O jednym z nich mówi się, co następuje: bhartavyā rakșañỹā ca patñ̄ hi patina sadā (Mbh.III.67.13), czyli „żona powinna zawsze być strzeżona przez męża”. Czasem wspomina się nawet o tym, że opiekują się oni wszelkimi stworzeniami - sarvabhütahite rata, co oznacza „znajdował rozkosz w szczęściu wszystkich istot” (np. Mbh.III.277.7). Są umiłowani przez swych poddanych (prajākāma). Wielokrotnie określani są

23 yaḥ khangayodhī laghucitrahasto mahāmiśca dhīmān /

24 Wszystkie terminy i fragmenty tekstów sanskryckich włączone w tekst artykułu - w tłumaczeniu autorki.

25 Zob. G. Dumézil, Mythe et épopée, vol. 1: L’idéologie des trois fonctions dans les épopées des peuples indo-européens, Paris 1968; vol. 2: Types épiques indo-européens: un heros, un sorcier, un roi, Paris 1972; N. Allen, The Hero's Five Relationships. A Proto-Indo-European Story, [w:] Myth and Mythmaking, Continuous Evolution of Indian Tradition. SOAS Collected Papers on South Asia, ed. J. Leslie, vol. 12, London 1995, s. 1-20. 
mianem ,wielkich duchem” (mahātma). Także i oni, podobnie jak Pandawowie, są mądrzy.

Jednym z władców tak właśnie opisywanych w pewnej opowieści wtrąconej w tok głównej narracji Mahabharaty jest król Madrów, Aśwapati:

W krainie Madrów był władca prawy i sprawiedliwy

Pobożny i opiekuńczy, z prawdą się nigdy nie mijał

Wielbiony przez swych poddanych, pan zmysłów, monarcha szczodry

Miłośnik stworzeń wszelakich, należne ofiary składał.

(Mbh.III.277.5-277.6) $)^{26}$

Podobnie jak informacje dotyczące zalet natury duchowej w opowieściach wtrąconych w główny wątek Mahabharaty często znaleźć można opis pożądanych cech fizycznych wielu władców. To właśnie w tych opisach nierzadko wspomina się o bogach, do których bohaterowie są podobni. Taki jest na przykład król $\mathrm{Nal}$, bohater jednej z najpiękniejszych opowieści miłosnych wtrąconych w tok fabuły głównej. Opisywany jest on jako podobny do niebianina Kandarpy (kandarpa iva rūpena). Nie ulega wątpliwości, że bohaterowie powinni swą urodą i pięknem przypominać niebian, być podobni do nieśmiertelnych, a w szczególności - ich władcy, Indry (devarājāsamadyuti). Często podkreśla się, że jaśnieją pięknem i blaskiem. W tym aspekcie podobni są między innymi do Aditi (ädityaiva tejasāa). Są też przystojni jak niebiańscy lekarze, bliźniacy Aświnowie (aśvinoh sadriśo rūpe). Porównuje się ich do praojca ludzkości, mitycznego Manu (sākșādìva manuh svayam). W rozmaitych kontekstach padają pytania o to, czy poszczególni bohaterowie to mężczyźni, czy niebianie, czy może istoty półboskie, takie jak wspominani wyżej Gandharwowie czy Jakszowie (ko'yam devo nu yakșo nu gandharvo bhavișyati). Nierzadko opisuje się ich jako „krzepkich i urodziwych młodzieńców".

Wzorcowi bohaterowie - władcy powinni być zatem przystojni, mieć wspaniałe ciało (rüpavan). Jego kształt powinien nie mieć sobie równych na ziemi. Uroda bohatera często dotyczy opisywanego w stereotypowy sposób oblicza: ma mieć orli nos i oczy podobne do lotosów (padmanibhikșaṇa). Często mówi się, że oczy bohatera są ogromne (viśáläkșan). Cała twarz ma być podobna do księżyca (candrābhavaktra, induvadana), a doskonałością ma być równa tak słońcu, jak księżycowi (ravisomasamaprabha).

W szczególnych przypadkach, najczęściej wtedy, gdy wydarzenia sprawiają, że bohater jest emocjonalnie poruszony, jego oczy opisywane są jako nabiegłe krwią, czerwone, przerażające. Tak jest na przykład we fragmencie opowieści o Ramie, w jej wersji zamieszczonej w Mahabharacie (Mbh.III.261.9) ${ }^{27}$. Bohater powinien być mężnym wojownikiem (vīra, śüra) i dlatego często jest określany jako mocny, waleczny (balin). Jest pogromcą wrogów (aridamana, arimardana), zdobywcą miast wrogów (parapuramjaya), stoi na czele armii (akșauhin̄ipati). Najczęściej ma mocarne, długie ramiona (mahābāhu, dīrghabāhu), które służą

${ }^{26} \bar{a} \bar{s} \bar{n}$ madreșu dharmātma rājā paramadhārmikah / brahmanyaśca śaranyaśca satyasambandho jitendriyah // yajvā dānapatirdakșa paurjānapadapriyah / pārthivo 'śvapatirnāma sarvabhūtahite ratah //

${ }^{27}$ lohitākșam mahābāhum mattamātangāminam / dīrghabāhum mahoraskam nīlakuńcitamürdhvajam // 
mu w walkach z wrogami. Kształt tych ramion często porównywany jest do maczug (daṇda). Bohaterów nierzadko, ze względu na moc, jaką powinni posiadać, porównuje się do groźnych zwierząt, takich jak tygrysy czy lwy (rājāśārdūla, naravyāghra). Zdarzają się też porównania do zwierząt podkreślające przede wszystkim sposób poruszania się. Wtedy najczęściej przywoływane są lwy (simha) lub słonie (gaja).

W jednym z opisów, który dotyczy kroczących razem królów, znaleźć można wiele z wymienionych cech:

Wkroczyli wtedy królowie przez wrót złoconych podwoje, podobni lwom niewzruszonym co w górskie pieczary idą.

Na miejscach swoich usiedli, wszyscy kwiatami uczczeni, w uszach kolczyki lśnią złote, klejnotów blask widać wokół.

Monarchów tych thum tam się zebrał, tygrysom górskim podobnych. Jak węże w rzece się kłębią.

Mężowie ci byli przystojni, ich twarze jak gwiazdy piękne, co w niebie blask roztaczając błyszczą wspaniale u góry.

Ramiona władców mocne, choć delikatne wielce. Wężom strasznym podobne, bestiom o głowach pięciu.

(Mbh.III.54.3-54.7) $)^{28}$

Dłuższy opis bohatera doskonałego pod względem urody można znaleźć na przykład w opowieści o Nalu i Damajanti. Damajanti mówi o mężu między innymi tak:

Jeśli dziś Nala nie ujrzę, co licem jak księżyc piękny, męża pełnego cnót wszelkich - z pewnością w proch się obrócę.

Gdy w ramion jego objęciu nie spocznę dziś delikatnym, nie dotknę męża mojego - z pewnością w proch się obrócę.

I jeśli wkrótce nie przyjdzie mąż mój, Niszadhów pan wielki, co jak grzmot burzy jest straszny - z pewnością w proch się obrócę.

Gdy nie pospieszy dziś do mnie Nala, co Indrze jest równy, co jako wielki lew kroczy $\mathrm{z}$ pewnością $\mathrm{w}$ proch się obrócę.

(Mbh.III.71.9-71.12) ${ }^{29}$

Fragmenty tekstu Mahabharaty, które zanalizowano w artykule, dają podstawy, by na postawione na początku pytania odpowiedzieć w sposób twierdzący. Zgromadzony materiał pozwala wskazać typowe, wielokrotnie powtarzające się w opisach bohaterów - władców cechy. Zarówno zalety ducha, jak i walory natury fizycznej powtarzają się nieodmiennie w wystarczająco wielu kontekstach, by można było mówić o toposie bohatera epickiego na podstawie fragmentów

28 surabhisragdharāḥ sarve sumṛștamaṇikuṇ̣alāh // tām rājāsamitim pūrṇām nāgairbhogavatīmiva /sampūrṇām puruṣvyāghrairvyāghrairgiriguhāmiva // tatra sma pīna dṛ́syante bāhavah parighoṣpamāh / ākāravantah suślakṣnāh pańcaśīrșā ivoragāh // sukeśāntāni cārūṇi sunāsāni śubhāni ca / mukhāni rajńām śobhante nakṣatrāṇi yathā divi //

${ }_{29}$ adya candrābhavaktram tam na paśyāmi nalam yadi / asmikhyeyaguṇam vīram viniśișyāmyāmyasaṃśayam //yadi vai tasya vīrasya bahvornādyāhamantaram / praviśāmi sukhasparśam viniśișyāmyāmyasaṃ́ayam //yadi mām meghanirghoṣo ’nopagacchati naișadhah / adya cāmīkaraprakhyo viniśișyāmyāmyasaṃśayam // yadi mām siṃhavikrānto mattavāraṇavāraṇah / nābhigacchati rājendro viniśișyāmyāmyasamśayam // 
wybranych z Mahabharaty. Są one na tyle typowe i powtarzają się bądź w formie epitetów, bądź dłuższych fraz czy zdań, że z pewnością można stwierdzić, iż ich użycie nie było przypadkowe. Władca w Mahabharacie najczęściej ukazywany jest jako postać doskonała, w swej doskonałości podobna do bogów czy istot półboskich. Jest wyposażony w zestaw cech, które pozwalają na takie właśnie porównania. Jest wielki duchem, prawy, sprawiedliwy i szczodry, szczególnie względem braminów. Odprawia przepisane prawem ofiary. Dba o swoich poddanych, opiekuje się zarówno nimi, jak i swoją małżonką. Ważne jest dla niego szczęście i dobrobyt wszystkich stworzeń. Jest mężem doskonałym także ze względu na swoje cechy fizyczne. Jest mocny i waleczny, a jednocześnie potrafi być delikatny i uważny. Także swoją urodą dorównuje niebianom. Błyszczy i lśni pięknością. Jego ramiona są mocarne, oblicze podobne jest do księżyca i słońca. Włosy ma ciemne, oczy ogromne, podobne do lotosów bądź ich płatków. Jest to niewątpliwie wyobrażenie władcy doskonałego w każdym z możliwych wymiarów.

Oczywiście zdarza się, że w Mahabharacie można znaleźć w niektórych epizodach wyobrażenia postaci ukazujące władców niespełniających co najmniej niektórych z opisanych wyżej wymogów. Są to najczęściej królowie - bohaterowie negatywni. Czy ich przedstawienia sprawiają, że nie można mówić o toposie indyjskiego władcy doskonałego? Z pewnością nie. Przemawia za tym choćby niewielka liczba takich epizodów, oraz brak szczegółowych, powtarzających się cech opisywanych bohaterów.

\section{Bibliografia}

\section{Tekst źródłowy}

The Mahābhārata, eds. V.S. Sukthankar et al., vol. 1-19, Poona 1933-1966.

\section{Bibliografia ogólna}

Allen N., The Hero's Five Relationships. A Proto-Indo-European Story, [w:] Myth and Mythmaking. Continuos Evolution in Indian Tradition. SOAS Collected Papers on South Asia, ed. J. Leslie, vol. 12, London 1995, s. 1-20.

Brockington J. L., Righteous Rāma. The Evolution of an Epic, Delhi 1984.

Brockington J.L., The Sanskrit Epics, Leiden 1998.

Buitenen J.A.B. van, The Mahābhārata. The Book of the Beginning, translated and edited by J.A.B. van Buitenen, Chicago-London 1973.

Buitenen J.A.B. van, The Mahābhārata. The Book of the Forest, translated and edited by J.A.B. van Buitenen, Chicago-London 1975.

Byrski M.K., Spotkanie z hinduizmem, Warszawa 2016.

Dmochowski F.K., Sztuka rymotwórcza, Wrocław 1956.

Dumézil G., Mythe et épopée, vol. 1: L’ideologie des trois fonctions dans les épopées des peuples indo-européens, Paris 1968; vol. 2: Types épiques indo-européens: un heros, un sorcier, un roi, Paris 1971.

Dowson J., A Classical Dictionary of Hindu Mythology and Religion, Geography, History and Literature, Delhi 1987. 
Hopkins E., Epic Mythology, Strassburg 1915.

Jakimowicz A., Sztuka Indii, Warszawa 1967.

Jakimowicz-Shah M., Metamorfozy bogów indyjskich, Warszawa 1983.

Jani A.N., The Mahābhārata as an Organic Growth of the Oral Literary Tradition in Ancient India, [w:] The Mahābhārata Revisited. Papers presented at the International Seminar on the Mahābhārata organized by the Sahitya Akademia at New Delhi on February 17-20, 1987, ed. R.N. Dandekar, New Delhi 1990, s. 71-85.

Macdonell A.A., A History of Sanskrit Literature, Delhi 1990.

Milewska I., Ze studiów nad Mahabharata, Kraków 2013.

Milewska I., Nala and Damayantī - Indian Epic Love Story in the European Tradition, [w:] Rethinking Orient. In Search of Sources and Inspirations, Frankfurt am Mein 2017, s. 127-141.

Monier-Williams M., A Sanskrit-English Dictionary Etymollogically and Philologically Arranged withh Special Reference to Greek, Latin, Gothic, German, Anlo-Saxon and Other Cognate Indo-European Languages, Delhi 1993.

Mylius K., Historia literatury staroindyjskiej, Warszawa 2004.

Rocher L, The Purānas, Wiesbaden 1985.

Stownik mitologii hinduskiej, Warszawa 1994.

Sullivan B.M., Kṛṣna Dvaypāyana Vyāsa and the Mahābhārata. A New Interpretation, Leiden 1990.

Swayambhuwa M., Manusmryti czyli Traktat o Zacności, przełożył z oryginału sanskryckiego, wstepem, przedmowa, przypisami i słowniczkiem opatrzył Maria Krzysztof Byrski, Warszawa 1992.

Święcicki J.A., Literatura indyjska, t. 4, Warszawa 1902.

Wilkins W.J., Hindu Mythology, New Delhi 2013.

Winternitz M., A History of Indian Literature, vol. 1, Delhi 1990. 